\title{
Evaluating local multi-stakeholder platforms in forest management in Ontario
}

\author{
by Mark Robson ${ }^{1}$ and Len M. Hunt ${ }^{2}$
}

\begin{abstract}
Ontario's Local Citizens' Committees (LCCs) are the oldest local multi-stakeholder platforms in forest management in Canada (since 1994) and one of the most researched. This paper is a meta-analysis of LCC research from large-scale surveys, document analysis of audits and case study interviews of members from two LCCs. Multi-stakeholder Platforms are expected to lead to better and more acceptable decisions than traditional approaches because they involve multiple stakeholders; consequently, the focus of the paper is on stakeholder representation and success. Our analysis concludes that representation is an issue and that LCCs have a mixed level of success.
\end{abstract}

Key words: public participation, success, representation, surveys, interviews

\begin{abstract}
RÉSUMÉ
Les comités locaux de citoyens en Ontario (CLC) constituent la plus ancienne plateforme locale de regroupement des intervenants en matière d'aménagement forestier au Canada (depuis 1994) et l'une des plus étudiée. Cet article est une analyse complète de la recherche sur les CLC comprenant des sondages à grande échelle, lanalyse des documents des audits et les entrevues des membres réalisées lors détudes de cas de deux CLC. Les plateformes constituées d'intervenants diversifiés sont perçues comme pouvant permettre de meilleures décisions et qui sont plus acceptables que lors d’approches traditionnelles parce quelles impliquent plusieurs intervenants; en conséquence, l'objet premier de cet article porte sur la représentation des intervenants et le succès atteint. Notre analyse conclue que la représentation constitue un défi et que les CLC connaissent différents niveaux de succès.
\end{abstract}

Mots clés : participation du public, succès, représentation, sondages, entrevues

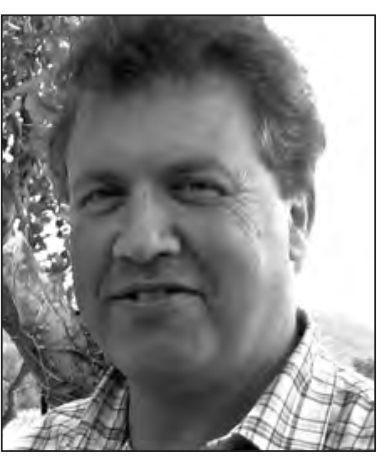

Mark Robson

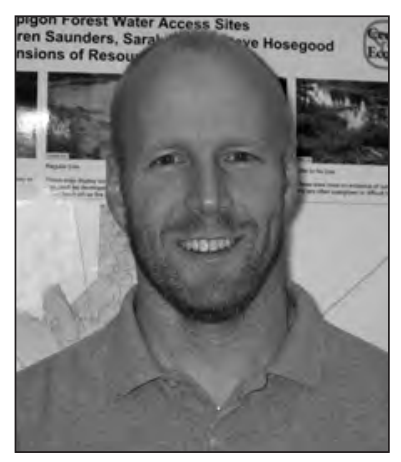

Len M. Hunt

\section{Introduction}

Multi-stakeholder participation in forest management decision-making has evolved considerably in Ontario. From informal and haphazardly planned, legal obligations now exist that require formal involvement of various stakeholder groups within forest management decision-making (e.g., Crown Forest Sustainability Act 1994). Formal involvement consists of three scales of scope and geography. First, at a provincial scale, two formally appointed committees exist: the Provincial Forest Policy Committee and the Provincial Forest Technical Committee (EAB 1994). The committees provide advice on forest policy and a check to ensure that the best available science is incorporated. The committees include a range of stakeholder and professional discipline representatives that are chosen by the Ontario Ministry of Natural Resources (OMNR). Second, three formally appointed Regional Advisory Committees exist to provide the OMNR with advice and recommendations on forest and other resource management issues on a regional scale. Finally, dozens of Local Citizen Committees (LCCs) exist "to advise the Minister on the preparation and implementation of Forest Management Plans and on any other matters referred to the committees by the Minister" (Crown Forest Sustainability Act 1994, c.25, s. 14).

This study examines LCCs as an advisory type of community-based, permanent multi-stakeholder platform in forest management in Ontario. In particular, we evaluate the success of LCCs among a variety of criteria that includes a special emphasis on representation.

Multi-stakeholder platforms (MSP) are "[D]ecision-making bodies (voluntary or statutory) comprising different stakeholders who perceive the same resource management problem, realise their interdependence for solving it, and come together to agree on action strategies for solving the problem" (Steins and Edwards 1999: 244). Advisory MSPs are a central component of forest planning processes in at least nine provinces and are required in five: Ontario, British Columbia, Alberta, Manitoba and New Brunswick (Parkins et al. 2006). They are also a condition for certification initiatives

\footnotetext{
${ }^{1}$ Community-based Forest Management International, 44 Scarboro Beach Blvd., Toronto, Ontario M4E 2X1. E-mail: mrk_rbsn@yahoo.ca

${ }^{2}$ Centre for Northern Forest Ecosystem Research, Ontario Ministry of Natural Resources.
} 
such as the Canadian Standards Association Sustainable Forest Management system (Canadian Standards Association 2002) and the Forest Stewardship Council's National Boreal Standard (Forest Stewardship Council 2004). Consequently, assessments of advisory MSPs can inform other researchers and practitioners about their potential strengths and weaknesses.

The emergence of MSPs as a type of "participatory democracy" complements the gap left by traditional "representative democracy" with a participatory approach that represents stakeholders through "constituent" groups. It acknowledges the skills and knowledge of stakeholder representatives and their desire to engage in meaningful discussions in the search for solutions to common resource management problems (Faysse 2006). We define stakeholders as groups who have an interest in forest management decision-making who influence or can influence decisions and those that are affected by them (Hemmati 2002). MSPs are, therefore, places where representatives come together to represent the interests and knowledge of their constituencies and act on behalf of their stakeholder groups (Wollenberg et al. 2004).

MSPs are expected to lead to better and more acceptable decisions than state-led processes that do not involve stakeholder participation (Hemmati 2002) and one-to-one negotiations (Steins and Edwards 1999). This is based on three key assumptions regarding MSPs: that they have more information as they involve all stakeholders, that they have greater self interest in achieving satisfactory solutions (Berkes et al. 1989) because decision-makers are directly impacted by their decisions, and that stakeholders are more likely to accept a solution that they have been involved in formulating. Participation by all stakeholders is also considered superior to one-to-one negotiations at facilitating integrative negotiations and discovering win-win solutions (Faysse 2006).

Permanent MSPs use consensus-building (Innes and Booher 1999) when interfacing with natural resource agencies. Consensus-building is relationship-centred rather than outcome-centred (Estes 1984) because it is more focussed on the process of arriving at decisions rather than formal agreements. It differs from traditional negotiation in that stakeholders are encouraged to accommodate rather than compromise the interests of group members (Jackson 2001). Consensus is used instead of majority rule to ensure that all individuals are heard and respected and that discussions are based on interests rather than constituency positions (Fisher and Ury 1981).

Defining MSP success, therefore, needs to go beyond the typical focus on short-term outcomes such as the achievement of agreements (Innes and Booher 1999) because agreement can be reached even if a process is regarded as a failure, breaks down, is poorly informed, produces unanticipated results or is infeasible. Criteria of success need to include key aspects such as fairness of a process. However, the most important criteria of success may be long-term intangible outcomes such as the development of cooperative relations among and between stakeholders and agencies.

We examined Ontario's LCCs to answer two research questions related to representation and success. First, how representative are and to what extent do LCCs act on behalf of stakeholder groups? Second, what is the success of LCCs in terms of process and short- and long-term outcomes? Data from a case study, Independent Forest Audits, and two social surveys of LCC members were used to answer these questions.

\section{Representation}

Representation is a key criterion for evaluating the success of public participation processes (Rowe and Frewer 2000, Mascarenhas and Scarce 2004, Sheppard and Meitner 2005) because a key objective of public participation is to give stakeholders a voice. Good representation also permits MSP stakeholders to consider many perspectives and learn from each others' experiences. It is also a democratic ideal for public participation processes, especially for management of goods such as publicly owned forests.

Researchers who study representation in natural resource management typically evaluate the range of stakeholder groups formally represented on an MSP against a democratic ideal (i.e., composition). This composition approach often focusses on elite notions of representation where only the interested, informed, educated, free-scheduled or threatened groups get involved in forest management issues (Dennis 1988, Shindler et al. 1993, Parkins and Mitchell 2005). Researchers have also identified excluded individuals by comparing the characteristics (socio-demographic and others), attitudes, and environmental value orientations of MSP members and a population (e.g., McFarlane and Boxall 2000, Jabbour and Balsillie 2003, Wellstead et al. 2003). Other researchers have examined whether barriers exist that prevent individuals from accessing decision-making processes (e.g., Reed and Varghese 2007). The exclusion of specific individuals or perspectives from a process can undermine its legitimacy. Furthermore, this exclusion reduces the ability of processes to result in an understanding of and respect for multiple perspectives and an appreciation of the different knowledge held by individuals.

Identifying a population of interest is critical when evaluating representation from a composition perspective. While MSPs are often criticized for their poor representation of the broader population of interest (Dennis 1988), this criticism is dependent entirely on how one defines a population of interest and representation. In its ideal form, MSPs should include all parties who have a stake in decisions (Faysse 2006). In reality, some groups may be excluded from platforms because of concerns over how their inclusion may affect balances of power. Even the definition of stake is arbitrary. For resources such as publicly owned forests, all citizens have a stake in decision-making. However, the decisions over resource use and development will likely affect some parties more than others. These varying effects along with capacity issues may affect the interest and ability of parties to become involved in MSPs.

Parkins and Mitchell (2005) noted that how advisory committees function can exclude participation by stakeholder representatives. Individuals with specific characteristics or perspectives may have great difficulty in actively participating in MSPs. For example, the highly technical nature of information presented to individuals results in poor comprehension of material and creates a barrier for effective dialogue (Robson et al. In press).

Compositional differences based from external and internal exclusions are not the only factors that affect representation. The way MSPs function may affect representation. Role- 
playing by members may increase knowledge of other points of view and provide a way to resolve problems in composition (Parkins 2002). If existing members are aware of missing perspectives and are willing to champion those perspectives at meetings, it is possible to overcome the consequences of poor composition of MSPs.

The efforts spent by representatives on MSPs are also critically important to achieve adequate representation. For instance, individuals who do not regularly participate in meetings are unable to represent their constituencies. Also, they cannot represent their constituencies if they do not stay abreast of what they desire and explain why they have to deviate from those desires at times.

\section{Success}

Successful MSPs can result in a well-functioning group that develops high-quality decisions and social and human capacity. Researchers evaluate success based on process or short- or long-term outcomes. Process-based evaluations examine perspectives from either participants or experts. Participantbased evaluations use self-evaluations by members of the process. This research attempts to link perceptions of the structure and function of the process to general evaluations of success in terms of short-term outcomes such as satisfaction, fairness, and/or effectiveness (e.g., Lauber and Knuth 1999, Charnley and Engelbert 2005, Hunt and McFarlane 2007). The fair process effect (Folger et al. 1979) is a common finding of this research. This effect explains why outcomes from processes are viewed favourably when individuals perceive that the process used to make the decisions is fair. Fairness is typically achieved through voice (Lind and Tyler 1988) whereby individuals are able to communicate their perspectives in a process where decision-makers are trusted (e.g., a court of law).

Expert-based evaluations of success are typically conducted by first identifying key criteria of decision-making processes and outcomes and then determining whether these criteria are present. Past research suggests that successful processes should address process criteria of representation, influence, transparency, clear mandate, short-term outcomes including agreements on plans (Innes 1999, Tuler and Webler 1999, Mascarenhas and Scarce 2004) and long-term outcomes including the development of social and human capital (trust and learning) (Rowe and Frewer 2000, Sheppard and Meitner 2005). Consequently, MSPs that have operated for an extended period may achieve significant gains in the quality of participation compared to other public participation processes such as one-time public meetings.

\section{LCCs and Forest Management Planning}

Following the Class Environmental Assessment (EAB 1994), OMNR was mandated to provide its local administrative district publics with an opportunity to become meaningfully involved in decisions relating to local forest resources on Ontario's commercially viable public timberlands. This mandate was in direct response to the Ontario Federation of Anglers and Hunters and Northern Ontario Tourism Outfitters Association Coalition and its demand for more meaningful consultation (OFAH and NOTOA 1991) to redress their concerns that forest management did not adequately consider non-timber values. Public timberlands comprised 45.3 mil- lion hectares or $64.3 \%$ of the forests of the Province of Ontario and incorporates or includes parts of 21 districts, each of which has one or more LCCs (OMNR 2002).

A small group of three to five support staff, including the local district manager and foresters from the local district office, typically convene and coordinate LCCs. While groups, existing LCC members, or the district manager can nominate LCC members, the district manager must approve any nomination. LCCs include a mix of stakeholders with economic interests (e.g., forestry company representatives, forestry company workers, independent logging contractors, tourist operators, trappers, bait fishers) and leisure interests (e.g., anglers, hunters, non-consumptive recreationists) along with aboriginal people and others who represent environmental organizations, local chambers of commerce, and the general public.

LCCs advise interdisciplinary planning teams of experts (OMNR, forestry company and an LCC representative) during the preparation of forest management plans. A representative from OMNR and/or the license holder acts as the chair of the planning team. LCCs begin advising on the preparation of a plan 27 months prior to renewal before forest operations begin on April 1 in a renewal year. During plan preparation, LCC members nominate an individual to represent them on the planning team and joint meetings between the plan author and LCC are held at agreed-upon stages of the planning process. LCCs also assist in monitoring plan implementation and provide advice to district managers if amendments to forest management plans are required during plan implementation ${ }^{3}$.

LCCs develop their own procedural rules such as election of a chair, frequency of meetings, and meeting agendas subject to the Terms of Reference for LCCs that is approved by the District Manager. Members are reimbursed for reasonable out-of-pocket expenses and OMNR provides district office support to assist in the conduct of committee affairs and to provide information. LCCs are required to produce reports of their activities, including discussions of problems and issues addressed by the committee, assessments of the co-operation provided to the committee by OMNR, assessments of the effectiveness of the committee structure and recommendations for changes at various stages during the planning process. These reports become part of the publicly available forest management plan (EAB 1994). Independent Forest Audits are also conducted every five years to assess licensee compliance and the effectiveness of forest management planning, including LCCs. While audits address public consultation, they are not required to comment on non-rule-related issues such as satisfaction.

\footnotetext{
${ }^{3}$ LCCs are intended to improve and not replace participation by the general public and native communities who also have opportunities for ongoing participation through a parallel five-stage public consultation process. As a result, LCC representatives are expected to attend all public information centres. Aboriginal communities have the additional option of participating through a separate native consultation process. When LCC members, the general public or aboriginal communities are not satisfied with the planning process, they can trigger a conflict resolution process within OMNR or initiate a "bump-up" request to a full environmental assessment administered by the Ontario Ministry of Environment.
} 
The nature and experience of Ontario's LCCs is potentially unique. LCCs differ from other multi-stakeholder advisory platforms in Canada in three fundamental ways: they are sponsored by the provincial government; they have the highest proportion of volunteer members and members who represent the public at large and; the members' motivations to participate are most likely related to contribute to the planning of a public resource (Parkins et al. 2006). Consequently, notions that stakeholder forms of civic engagement are elitist (Dennis 1988, Shindler et al. 1993, Parkins and Mitchell 2005) may not hold for Ontario.

LCCs have existed for the longest period of time (since 1994), have members who have been involved for the secondlongest period of time (members have served an average 5.4 years) and, on average, are the smallest-sized forest advisory committees (average of 16 members) in Canada (Parkins et al. 2006). These facts suggest that LCCs may have been more successful at developing social and human capital than other Canadian MSPs in forest management.

\section{Methods}

We used data from four different sources to evaluate representation and the success of LCCs (Table 1). Two data sources used social surveys that provided information about LCC members and their views and evaluations of forest management. The 2001 survey was conducted to compare the characteristics and views of LCC members to random samples of northern and southern Ontarians (see Hunt and McFarlane 2002, 2007; McFarlane and Hunt 2006 for more details). The 2004 survey enabled a comparison of characteristics and views of LCC members to members of other Canadian forestrelated MSPs (Parkins et al. 2006).

The third data source was based on responses to questions in face-to-face interviews with all of the members of two LCCs. These interview data were collected to identify how key consensus-building criteria influenced the development of social and human capital among LCC members and OMNR support staff (see Robson and Kant 2007 a, b for more details). The two LCCs differed by members' experience levels and selection criteria (members of the second LCC [LCC2] were more experienced and were more often selected to represent sectors rather than specific stakeholder group/organizations than were members of the first LCC [LCC1]).
The fourth and final data source was a content analysis of all Independent Forest Audits (IFAs) completed by auditors to evaluate compliance with associated Acts, manuals and guides and consistency between outcomes and objectives (OMNR 2007). The audits are based on eight principles of which one focuses on public participation (OMNR 2007). These reports were previously analyzed by Robson et al. (In press) to explore the role of information complexity as a barrier to public participation in forest management planning.

Representation of LCCs was evaluated using both composition and function-related criteria. To assess composition, we identified the population of interest to include all northern Ontario residents although we also compare LCC members and their responses to southern Ontarians to understand similarities/differences with distant urban populations in southern Ontario, where the overwhelming majority of Ontarians live. We focused on northern Ontarians because LCC members represent local interests within each of OMNR's administrative districts where forest management takes place. Consequently, over $95 \%$ of responding LCC members were located in northern Ontario. Over 60\% and almost $80 \%$ of southern and northern Ontarians, respectively, also agreed that concerns of local forest communities should be given a higher priority in forest management than concerns from more distant communities (Hunt and McFarlane 2002).

We used socio-demographic and other characteristics, environmental values, and attitudes towards forestry and forest management in Ontario to compare the composition of LCCs to northern and southern Ontario populations. Characteristics included gender, formal education, age, and dependency on forests for leisure and economic activities. Dependency was measured with survey questions that asked about forest use, dependency of a respondent or his/her family member for employment in resource management, and membership with fishing and/or hunting organizations. The environmental (forest) value orientation (ranging from anthropocentric, or human-centred, to biocentric, or nonhuman-related values) and attitudinal statements towards forestry and forest management questions were adapted from McFarlane and Boxall (2003). All analyses were statistically compared to the responses of LCC members and northern and southern Ontario respondents from the 2001 survey.

We also measured composition more generally through a content analysis of the Independent Forest Audits and inter-

Table 1. Data sources used to evaluate representation and success

\begin{tabular}{|c|c|c|c|c|}
\hline Year(s) & $\begin{array}{c}\text { Social survey \#1 } \\
2001\end{array}$ & $\begin{array}{c}\text { Social survey \#2 } \\
2004\end{array}$ & $\begin{array}{c}\text { Interviews } \\
2001\end{array}$ & $\begin{array}{l}\text { Independent forest audits } \\
\text { 2000-2004 }\end{array}$ \\
\hline Populations & $\begin{array}{l}\text { LCC members }^{1} \\
\text { northern Ontarians } \\
\end{array}$ & $\begin{array}{l}\text { Canadian forest advisory } \\
\text { groups (LCC members) }\end{array}$ & members from two LCCs & $\begin{array}{l}\text { audits of forest manage- } \\
\text { ment plans in Ontario }\end{array}$ \\
\hline Data collection & on site ${ }^{1}$, random sample $e^{2,3}$ & on site and mail & In person & $\begin{array}{l}\text { Web sites and published } \\
\text { reports }\end{array}$ \\
\hline Sample & $189^{1}, 691^{2}, 805^{3}$ & 253 (LCC members) & 20 & 57 \\
\hline Response rate (\%) & $\mathrm{NA}^{1}, 40.0^{2}, 53.8^{3}$ & NA & 100.0 & 98.3 \\
\hline Analyses & Quantitative & Quantitative & Content analysis & Content analysis \\
\hline
\end{tabular}

The difference between LCC members and other respondents is significant at the $\mathrm{p}<.05$ level.

$\mathrm{NA}$ - response rate is not applicable as no complete census of LCC members exists 
views. The audits reported on the proportion of LCCs that had a relatively balanced and wide range of interests represented in their memberships. For the interviews, we calculated the percentage of interviewees that agreed their LCC had representation from all relevant interests.

The functional part of representation was measured in several different ways. First, data from the interviews of LCC members were used to examine the development of social and human capital within each LCC. Specifically, we described whether the interviewees mentioned that they had equal access to information, respected and listened to each other, could question experts, and could challenge any assumptions made by experts. Second, this same data source provided assessments of participation in meetings by stakeholder representatives and of communications with members of stakeholder groups and the broader public. Finally, the 2004 survey data were used to assess whether members championed roles of other stakeholders by identifying roles that members were selected to represent and the roles they actually represented.

Evaluations of LCC success were based from self-evaluations from committee members. In the 2001 survey, LCC members were asked to use a five-point agree/disagree scale to rate the statement that "the LCC is effective at influencing local forest decision-making". The 2004 survey used the same rating scale for the statement "This committee is effective at influencing local forest decision-making". We provide summaries of these evaluations along with a comparison of ratings by LCC members to other forestry MSPs in Canada (Parkins et al. 2006).

Data from the Independent Forest Audits were used to evaluate LCC success in terms of influence on forest management planning. Therefore, the section on public consultation was analyzed for comments relating to the influence of LCCs. A list of themes was compiled based on the frequency that comments were reported in audits and each audit was reexamined to determine if, and how, each theme was addressed.

Finally, the interview data were used to evaluate success through outcomes from LCC participation. Short-term outcomes related to whether the forest management plan met the expectations of the LCC member and longer-term outcomes related to increasing the understanding of stakeholder and agency issues, increasing the cooperation between agency and stakeholders, increasing cooperation among stakeholders, and increasing confidence in the planning process. These indirect, long-term outcomes represent important developments for social and human capital.

\section{Results}

\section{Representation: composition}

Survey responses between LCC members and southern and northern Ontarians revealed important differences (Table 2). The LCC sample was more male-dominated $\left(\chi^{2}=111.8, \mathrm{df}=\right.$ $2, \mathrm{p}<0.01)$ and educated $\left(\chi^{2}=152.0, \mathrm{df}=14, \mathrm{p}<0.01\right)$ than were surveyed southern or northern Ontarians. While no differences in average age were observed $(\mathrm{F}=2.14, \mathrm{df}=2, \mathrm{p}=$ $0.11)$, differences existed among the standard deviations $(\mathrm{F}=$ 2.937, $\mathrm{df}=2, \mathrm{p}=0.05$ ) suggesting that LCC members were far less diverse in age than northern or southern Ontarians.

The LCC members had greater dependence on forests for the pursuit of leisure and economic activities than did other
Table 2. Characteristics of LCC members compared to southern and northern Ontario survey respondents

\begin{tabular}{lccc}
\hline & $\begin{array}{c}\text { LCC } \\
\text { members }\end{array}$ & $\begin{array}{c}\text { Northern } \\
\text { Ontario }\end{array}$ & $\begin{array}{c}\text { Southern } \\
\text { Ontario }\end{array}$ \\
\hline Male $^{*}$ & $93.0 \%$ & $53.1 \%$ & $51.2 \%$ \\
University educated $^{*}$ & $39.5 \%$ & $18.6 \%$ & $32.9 \%$ \\
Age (average) & 50.8 & 53.5 & 49.6 \\
Age (standard deviation) $^{*}$ & 11.6 & 27.1 & 23.3 \\
\hline
\end{tabular}

* significant difference between LCC and other respondents $(\mathrm{p}<0.05)$

From: Hunt and McFarlane (2002)

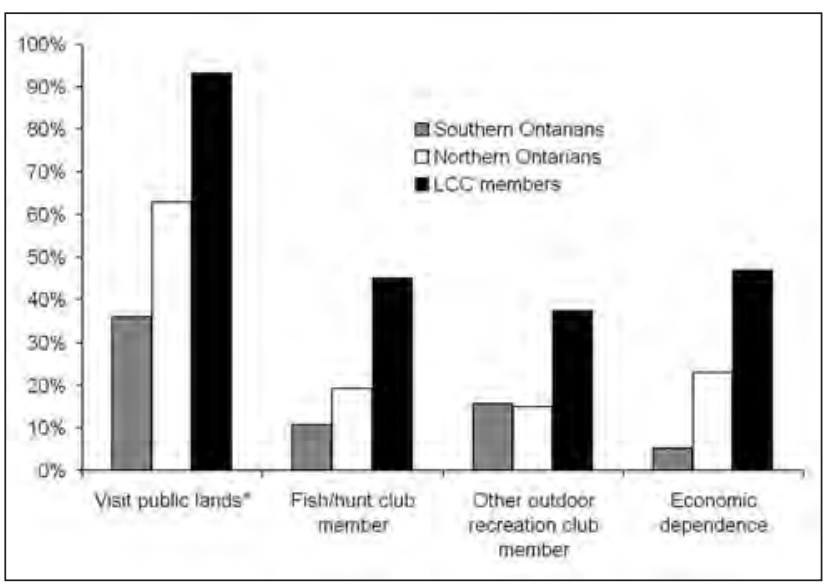

Fig. 1. Percentage of southern and northern Ontarians and LCC members in 2001 who depended on natural resources for leisure and economic activities (* visit of non-protected publicly owned forests, economic dependence - individual and/or household family member who relies on natural resources for employment].

residents (Fig. 1). LCC members were also most likely to have used non-protected public forest lands $\left(\chi^{2}=238.1, \mathrm{df}=2, \mathrm{p}<\right.$ 0.01 ) or to state that they belonged to fishing or hunting clubs $\left(\chi^{2}=1681.7, \mathrm{df}=2, \mathrm{p}<0.01\right)$ or general outdoor recreation clubs $\left(\chi^{2}=1735.7, \mathrm{df}=2, \mathrm{p}<0.01\right)$. These same individuals were most likely to have had a family member depend on resource management activities for employment $\left(\chi^{2}=64.2, \mathrm{df}\right.$ $=2, \mathrm{p}<0.01)$.

All survey respondents were asked to rate their agreement or disagreement with items from a forest (environmental) values scale (Table 3). On average, the LCC members had value orientations that were the most anthropocentric while southern Ontarians were most biocentric. The LCC members consistently expressed most disagreement with statements about the inherent worth and spiritual value of forests ${ }^{4}$. The LCC respondents were also more likely than southern Ontarians to value forests for economic and utilitarian perspectives. Less conclusive differences existed that LCC members valued economic and utilitarian perspectives more than northern Ontarians.

Survey respondents were also asked to rate a series of attitudinal statements towards forestry and forest management

${ }^{4}$ LCC members, however, expressed highest agreement with the statement that forests provide a sense of peace and well-being. 
Table 3. Mean agreement ratings ( $1=$ strongly disagree and $5=$ strongly agree) with value statements by Local Citizens Committee (LCC) members and surveyed southern and northern Ontarians

\begin{tabular}{|c|c|c|c|}
\hline Value category and statement & LCC & $\begin{array}{l}\text { Northern } \\
\text { Ontario }\end{array}$ & $\begin{array}{c}\text { Southern } \\
\text { Ontario }\end{array}$ \\
\hline \multicolumn{4}{|l|}{ Existence values: } \\
\hline It is important to maintain the forests for future generations & 4.82 & 4.79 & 4.82 \\
\hline $\begin{array}{l}\text { Whether or not I visit the forest as much as I like, it is important for me } \\
\text { to know that forests exist in Ontario }\end{array}$ & 4.65 & 4.54 & 4.56 \\
\hline \multicolumn{4}{|l|}{ Spiritual values: } \\
\hline Humans should have more respect and admiration for the forests & $4.19^{S, N}$ & 4.51 & 4.46 \\
\hline Forests let us feel close to nature & $4.29^{S, N}$ & 4.52 & 4.46 \\
\hline Forests rejuvenate the human spirit & $4.04^{S}$ & 4.17 & 4.20 \\
\hline Forests give us a sense of peace and well being & $4.36^{S, N}$ & 3.82 & 3.68 \\
\hline Forests are sacred places & $3.13^{S, N}$ & 3.41 & 3.46 \\
\hline \multicolumn{4}{|l|}{ Inherent worth: } \\
\hline \multicolumn{4}{|l|}{ Forests should have the right to exist for their own sake, regardless of human } \\
\hline Wildlife, plants, and humans should have equal rights to live and develop & $3.60^{S, N}$ & 4.00 & 4.03 \\
\hline $\begin{array}{l}\text { Forests should be left to grow, develop, and succumb to natural forces without } \\
\text { being managed by humans }\end{array}$ & $1.97^{S, N}$ & 2.52 & 2.82 \\
\hline \multicolumn{4}{|l|}{ Economic or utilitarian values: } \\
\hline Forests should be managed to meet as many human needs as possible & $4.37^{S, N}$ & 3.63 & 3.42 \\
\hline Forests can be improved through management by humans & $4.04^{S}$ & 4.06 & 3.89 \\
\hline $\begin{array}{l}\text { If forests are not threatened by human actions, we should use } \\
\text { them to add to the quality of human life }\end{array}$ & 4.10 & 4.06 & 4.04 \\
\hline $\begin{array}{l}\text { The primary function of forests should be for products and services that are } \\
\text { useful to humans }\end{array}$ & $2.69^{S, N}$ & 2.32 & 2.18 \\
\hline Forests should exist mainly to serve human needs & $2.45^{S}$ & 2.30 & 2.18 \\
\hline Forests that are not used for the benefit of humans are a waste of our natural resources & $2.23^{S, N}$ & 1.93 & 1.79 \\
\hline
\end{tabular}

$S, N$ indicates a significant $(\mathrm{p}<0.05)$ difference in response between LCC and southern and northern Ontarians, respectively

From: Hunt and McFarlane (2002)

in Ontario (Table 4). The LCC members were most likely to agree with statements about the multiple benefits provided from forestry, the sustainability of yield from forests, and the importance of economic benefits from forest management. The LCC members also had the highest level of agreement about the extent and quality of public participation opportunities believing that Ontarians have an adequate say in forest management and that the forest industry does not control too much of decision-making.

The content analysis of Independent Forest Audits (OMNR 2007) indicated that $68 \%$ of advisory committees (27 of Ontario's 40 forest management units) had a relatively balanced and wide range of interests represented in their memberships. Advisory committees on three $(8 \%)$ of the forest management units were also assessed by the auditors to have broad representation except for one or two key interests: usually remote tourism, naturalists, and/or First Nations representatives. On $25 \%$ of committees, however, the advisory committees did not represent a balance and/or wide range of interests.

Results from interviews with members of the two LCCs provide examples of the context of balanced and unbalanced LCCs (one was broadly representative of local stakeholders while the other was not). Ninety-one per cent of the interviewees from LCC2 agreed that its LCC had adequate representation of all interests. One LCC member stated:
"Last year we had a good cross-section of peopleexcellent. There was mining. There were trappers. There was tourism. There was business. We had a good cross section of people."

However, none of the interviewees from LCC1 agreed that it had adequate representation. One interviewee suggested that LCC1 had difficulty in attracting members from aboriginal people, the local municipality, and the local Chamber of Commerce populations as noted by:

"...we had trouble getting representatives from certain areas...that should have been interested...It was just we couldn't find someone from that group who would be interested."

\section{Representation: function}

We found that most interviewees agreed that the LCC functioned in a way to promote the building of social and human capital. For both LCCs, all interviewees agreed that they respected and listened to each other, had equal access to information and were able to question and challenge the assumptions of experts (Table 5).

With respect to respecting and listening to each other, an interviewee stated,

"Yeah. I don't think there's a problem there. I think if you might have brought up any concerns they were well listened to by the group..." 
Table 4. Mean agreement ratings ( $1=$ strongly disagree and $5=$ strongly agree) with attitudes about forests and forest management by Local Citizens Committee (LCC) members and surveyed southern and northern Ontarians

\begin{tabular}{|c|c|c|c|}
\hline Category and statement & LCC & $\begin{array}{l}\text { Northern } \\
\text { Ontario }\end{array}$ & $\begin{array}{l}\text { Southern } \\
\text { Ontario }\end{array}$ \\
\hline \multicolumn{4}{|l|}{ Public involvement: } \\
\hline $\begin{array}{l}\text { When making forest decisions, the concerns of communities close to the } \\
\text { forest should be given a higher priority than other distant communities }\end{array}$ & $4.15^{S, N}$ & 3.98 & 3.50 \\
\hline The forest industry controls too much of Ontario's forests & $3.05^{S, N}$ & 3.46 & 3.37 \\
\hline $\begin{array}{l}\text { Communities that depend on the forest for their economic well-being are } \\
\text { given adequate consideration in forest management }\end{array}$ & 2.94 & 2.78 & 2.98 \\
\hline The citizens of Ontario have enough say in forest management & $3.03^{S, N}$ & 2.27 & 2.27 \\
\hline \multicolumn{4}{|l|}{ Multiple benefits: } \\
\hline Forest management does a good job at including environmental concerns & $3.68^{S, N}$ & 3.20 & 3.16 \\
\hline $\begin{array}{l}\text { Forests are being managed successfully for a wide range of uses and values, } \\
\text { not just timber }\end{array}$ & $3.84^{S, N}$ & 3.35 & 3.27 \\
\hline Forests are being managed successfully for the benefit of future generations & $3.30^{S, N}$ & 2.76 & 2.75 \\
\hline $\begin{array}{l}\text { Ontario has enough protected areas such as provincial and national parks or } \\
\text { wilderness areas }\end{array}$ & $3.74^{S, N}$ & 2.84 & 2.58 \\
\hline $\begin{array}{l}\text { Forestry practices generally produce few long-term negative effects on the } \\
\text { environment }\end{array}$ & $2.96^{S, N}$ & 2.58 & 2.40 \\
\hline \multicolumn{4}{|l|}{ Sustained timber yield: } \\
\hline There will be sufficient wood in Ontario to meet our future needs & $2.98^{S, N}$ & 2.65 & 2.68 \\
\hline $\begin{array}{l}\text { Enough harvested trees are being replaced by planting new ones or by natural } \\
\text { seeding to meet our future timber needs }\end{array}$ & $3.17^{\mathrm{S}, \mathrm{N}}$ & 2.63 & 2.63 \\
\hline The present rate of logging is too great to sustain our forests in the future & $3.04^{S, N}$ & 3.60 & 3.61 \\
\hline \multicolumn{4}{|l|}{ Economic development: } \\
\hline $\begin{array}{l}\text { Economic stability of communities is more important than setting aside forests } \\
\text { from logging }\end{array}$ & $2.86^{S, N}$ & 2.56 & 2.42 \\
\hline The economic benefits from forestry usually outweigh any negative consequences & $2.93^{S, N}$ & 2.46 & 2.33 \\
\hline
\end{tabular}

$S, N$ indicates a significant $(\mathrm{p}<0.05)$ difference in response between LCC and southern and northern Ontarians, respectively

From: Hunt and McFarlane (2002)

Table 5. Percentage of interviewees that agreed with various process aspects of the functioning of the LCC

\begin{tabular}{lll}
\hline & $\begin{array}{l}\text { First } \\
\text { LCC } \\
\text { \% of } \\
\text { members } \\
\text { (n) }\end{array}$ & $\begin{array}{l}\text { Second } \\
\text { LCC } \\
\text { \% of } \\
\text { members } \\
\text { (n) }\end{array}$ \\
\hline Respect and listen to each other & $100 \%(9)$ & $100 \%(11)$ \\
Equal access to information & $100 \%(9)$ & $100 \%(11)$ \\
Question experts & $100 \%(9)$ & $100 \%(11)$ \\
Challenge assumptions & $100 \%(9)$ & $100 \%(11)$ \\
Communication with represented group & $89 \%(8)$ & $55 \%(6)$ \\
Communication with the broader public & $67 \%(6)$ & $64 \%(7)$ \\
Expression of broader interests & $89 \%(8)$ & $73 \%(8)$ \\
\hline
\end{tabular}

Regarding whether there was equal access to information, another interviewee responded,

"To my knowledge, anything we requested would be supplied and it would be asked if everybody wanted a copy. If there were just certain individuals that wanted information, it would be supplied."
Finally, on the issue of being able to question and challenge assumptions, an interviewee acknowledged,

"Yeah, everybody could ask any question you wanted because a lot of the questions...like I say, when you've got an expert in there, you have to ask questions because you don't know what they're talking about."

The interview data also were used to assess the efforts of the individual within and outside of the committee (Table 5). The interviewees reported that they attended about $70 \%$ of LCC meetings. Most interviewees also reported that they communicated with their represented group and the broader public. One member responded:

"We would actually have Spring and Fall meetings where trappers or all members are present. I'm on the Trapper Board. Well, it goes in spurts. It depends what's going on. I know in one month there they had the big issue down by the [name of lake] area. There was a bridge issue there. They were going to take it out and whatever. This is not trappers so much but local citizens wanting information on that."

Individuals from the first LCC were more likely than those from the second to communicate with their group. Most of the communication for both LCCs was one-way from the stakeholder representative back to the represented group.

LCC members in the survey were originally selected to represent industrial (i.e., forestry and other resource indus- 


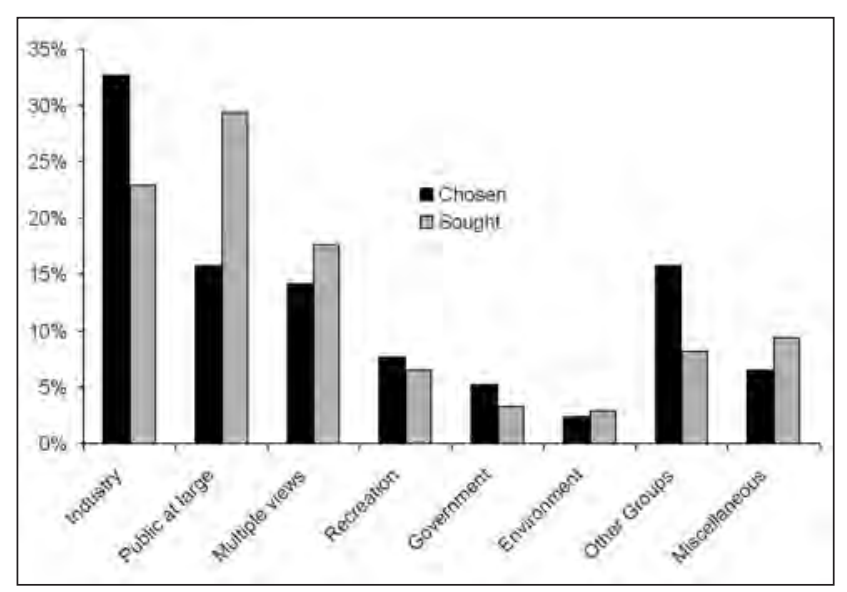

Fig. 2. Percentage of LCC members who were chosen to represent and who sought to represent different perspectives. From: Parkins et al. (2006)

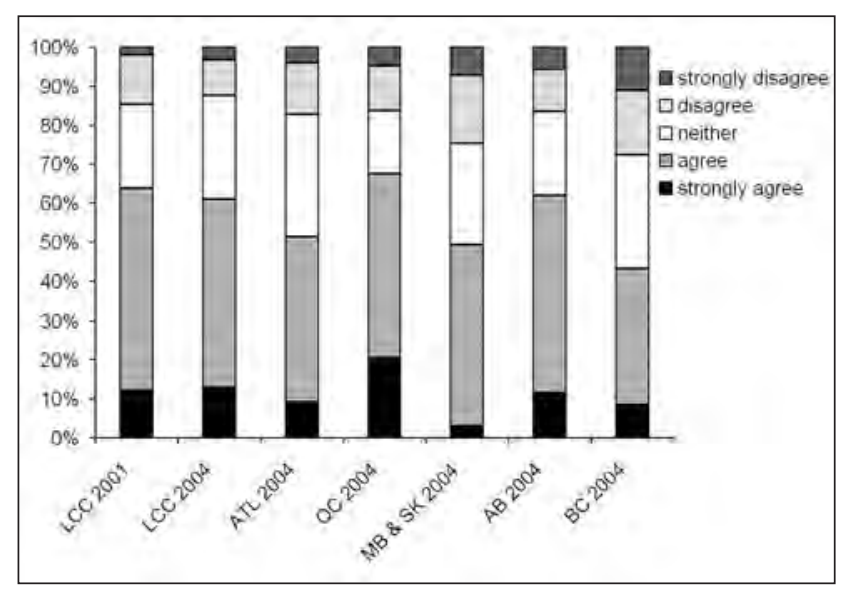

Fig. 3. Agreement/disagreement by forest advisory committee members about the effectiveness of their committee at influencing local forest decision making (ATL - includes Newfoundland, Nova Scotia and New Brunswick, QC - Quebec, MB \& SK - Manitoba and Saskatchewan, AL - Alberta, BC - British Columbia)

tries), public at large, other groups, and multiple view perspectives (Fig. 2). However, a significantly different distribution existed for whom LCC members sought to represent $\left(\chi^{2}=24.1, \mathrm{df}=7, \mathrm{p}<0.01\right)$. The LCC members were increasingly seeking to represent the public at large and multipleview perspectives, and were less likely to select industrial or other group perspectives.

\section{Success}

Almost two-thirds of the surveyed LCC members in 2001 agreed or strongly agreed that "The LCC is effective at influencing local forest decision-making” (Fig. 3). In fact, over four times as many respondents selected agree or strongly agree than disagree or strongly disagree with the statement. From the study of Canadian forest advisory group members, evaluations of "This committee is effective at influencing local forest decision-making" differed by origin of the member ( $\mathrm{F}$ $=6.2, \mathrm{df}=5, \mathrm{p}<0.01)$. While the LCC members evaluations
Table 6. Percentage of interviewees that agreed with shortand long-term outcomes that contribute to the effectiveness of the LCC

\begin{tabular}{|c|c|c|}
\hline Criterion & $\begin{array}{l}\text { First } \\
\text { LCC } \\
\text { \% of } \\
\text { members } \\
\text { (n) }\end{array}$ & $\begin{array}{l}\text { Second } \\
\text { LCC } \\
\% \text { of } \\
\text { members } \\
\text { (n) }\end{array}$ \\
\hline $\begin{array}{l}\text { Forest Management Plan } \\
\text { met expectations }\end{array}$ & $67 \%(6)$ & $82 \%(9)$ \\
\hline $\begin{array}{l}\text { Increase in understanding of stakeholder } \\
\text { and agency issues }\end{array}$ & $78 \%(7)$ & $100 \%(11)$ \\
\hline $\begin{array}{l}\text { Increase in cooperation between agency } \\
\text { and stakeholders }\end{array}$ & $100 \%(9)$ & $64 \%(7)$ \\
\hline $\begin{array}{l}\text { Increase in cooperation among } \\
\text { stakeholders }\end{array}$ & $100 \%(9)$ & $64 \%(7)$ \\
\hline $\begin{array}{l}\text { Increase in confidence in the } \\
\text { planning process }\end{array}$ & $56 \%(5)$ & $91 \%(10)$ \\
\hline
\end{tabular}

were more positive than those by group members from British Columbia $(\mathrm{t}=3.4, \mathrm{df}=315$, Bonferroni adjusted $\mathrm{p}<$ $0.01)$ and Manitoba and Saskatchewan $(t=2.7, \mathrm{df}=315$, Bonferroni adjusted $\mathrm{p}=0.05$ ), they were not statistically different from Atlantic, Quebec, or Alberta members.

Twenty-five percent (14) of the audit reports addressed satisfaction with level of influence on forest management planning decisions. While 36\% (5) of these reports revealed reasonable levels of public, LCC, and aboriginal satisfaction that concerns were heard and addressed by the decision-makers, 36\% (5) also indicated that LCCs felt that their concerns were ignored and/or would have preferred to have a more substantial role in the decision-making process. Because audits are not required to specifically address issues such as influence on decision-making, they likely do so only when the issues are important.

Interviews with members provided further evidence to assess the success of LCCs (Table 6). Most interviewees believed that the LCC increased understanding of stakeholder issues, cooperation between agency and stakeholders, and cooperation among stakeholders. For instance, one LCC member's response when asked if the meetings in which they engaged increased their understanding of stakeholder issues and opinions was:

"I think it always does because everybody's got a different view or how stuff affects them. Any member of the public...cottage owners, all kinds of things, tourist camp owners... and I think it educates you more as to what other peoples' expectations or needs or livelihood."

When asked whether their participation increased their cooperation with OMNR, one LCC member said:

"The management we have here in the area [local district office of OMNR] now is much, much improved and I think it works right from the girl [sic] in the front desk all the way up."

Similarly, when asked whether their participation increased their cooperation with other stakeholder representatives since the beginning of the process another LCC member said that: 
"...everyone feels free to communicate with each other. It's a totally different feeling than at the beginning."

Most interviewees also believed that the forest management plan met expectations, one LCC member saying:

"We didn't have a lot of problems with it that I can recall as far as our LCC was concerned. There wasn't a lot that came to us. There was some stuff."

However, some notable differences of opinion existed among members from the two LCCs. Members from the second LCC were almost unanimous about increasing confidence in the planning process with one stating,

"Well, in the fact that they are putting into place all of the stakeholders and the various aspects of it and there is some long-term planning. They aren't just willy-nilly going here or there. There's quite a bit a thought going into what the Ministry is doing now. They take very seriously all these different concerns probably more than I do because they have to deal with them day-to-day basically."

While almost one-half of interviewees from the first LCC disagreed with this increase:

"It's like I said, I think it's driven more by politics, by job creation than good forest management. And probably through no fault of the guys at Natural Resources. They probably zap them out of school and go into these jobs. They're probably just wide-eyed. Somebody out there is pulling the strings. We need so much fibre. Find me that fibre. Show me how to make this sustainable. So we'll design computer programs that make it look like it's a sustainable thing."

This poorer evaluation of the planning process occurred despite the greater increase in reported levels of cooperation between the agency and stakeholders and among stakeholders by interviewees from the first compared to the second LCC.

\section{Discussion}

We sought to answer two questions related to representation and the success of Ontario's advisory MSPs. Through numerous measures and four data sources, we conclude that issues of representation existed within these MSPs. While the data suggested that MSPs were successful in achieving most consensus-building process functions (e.g., respect, equal access to information), short-term and long-term outcome criteria, the findings were mixed with respect to influence on forest management decision-making.

The issues of representation were evaluated in terms of representativeness and functioning of LCCs. As with other researchers (Jabbour and Balsillie 2003, McFarlane and Boxall 2003, Wellstead et al. 2003), we found that MSPs were dominated by higher educated males, with little diversity in age, and who have strong dependence on resource management for economic and leisure pursuits. The MSPs also had a greater proportion of individuals that held anthropocentric views towards forests and forest management than did populations of northern or southern Ontarians. When representation was noted as an issue, the Independent Forest Audits suggested that perspectives from aboriginal people, environment, and tourism stakeholders were most often absent. These results suggest that MSPs are missing perspectives from particular groups, possibly those with more environmentallyconscious views.

We can only provide some circumstantial evidence to explain why some individuals such as aboriginals, environmentalists, tourist operators, and women are poorly represented on some MSPs. Lack of interest in participating on an MSP due to a previous negative experience was an issue for aboriginal and a few stakeholder groups in one of the two case studies. These negative experiences often related to internal exclusion (Parkins and Mitchell 2005), whereby barriers existed that prevented individuals from truly bringing their perspectives into meaningful deliberations. Hunt et al. (2009) noted that some tourism operators in Ontario did not participate on MSP committees because they perceived that their desire to protect remoteness was not consistent with other members who preferred increased road access. Likewise, Reed and Varghese (2007) implied that women's perspectives are not always welcomed on committees. A couple of the Independent Forest Audits suggested that the challenge in recruiting and retaining remote outfitter representatives and aboriginal people may also be attributed to long distances between the potential representatives' residence and/or place of work and the advisory committee meeting locations.

Following the reasoning of Wellstead et al. (2003), the fact that MSPs do not mirror the population of northern Ontarians is not in itself troubling. They argued that how an advisory group functioned was much more important than its composition. Likewise, Parkins (2002) suggested that roleplaying by advisory group members can help to overcome the exclusion of different viewpoints. We observed this tendency for role-playing by some MSP members. Members quite often stated that they sought to represent perspectives such as the general public or multiple views that differed from their perspective that they were chosen to represent. This was supported in the case studies where members from both MSPs also expressed broader interests than that of their represented groups. While this willingness to role-play is encouraging, differences in gender balance, aboriginal participation, and environmental perspectives are not (and maybe cannot be) adequately addressed through role-playing by MSP members.

A few other interesting findings of the function of MSPs were found. Interviewees from the two MSPs stated that they regularly participated in meetings, that no barriers to access or questioning information existed, that respect existed for different viewpoints, and that they communicated with their membership and the general public. However, from the interview data with the MSP that represented sector interests and not stakeholder groups, less communication occurred with the represented sectors. Sectors, being unorganized, highly constrained the ability of representatives to communicate to their constituencies. In contrast, where stakeholder groups were formally represented, communication was much more frequent.

Communication tended to be one-way from the stakeholder representative to the represented group. This indicates that constituencies had a limited level of control over their representatives. Because the capacity of sectors and groups to ensure accountability was limited, it is unknown how well the interests of constituencies were actually represented at MSP meetings. Without accountability, autonomous representatives may become more self-interested and less responsive to 
constituency interests. Without the countervailing force of constituency accountability, representatives may also become more subject to co-option (Singleton 2000) by the OMNR. This would sever the links between MSPs and the broader public constituencies that they are supposed to represent.

Data from survey research and most of the interview data tended to support the conclusion that MSPs were successful in many process and short-term outcomes and resulted in desirable long-term outcomes for members. In the surveys, about two in three members agreed that the MSP was effective at influencing local forest management decision-making. In a formal analysis of this result, Hunt and McFarlane (2007) found that perceptions of receiving credible information, trust in decision-makers, control, and efficiency of the process were instrumental in explaining evaluations of effectiveness. Consistent with the fair process effect (Folger et al. 1979), control, which included the opportunity to voice concerns, was the most important factor that explained variations in effectiveness ratings. Greater perceptions about one's ability to communicate concerns within the MSPs resulted in increased evaluations about the fairness of and outcomes from the process.

The interviews with MSP members found that a majority of members agreed that the forest management plan met expectations and that they developed an increased confidence in the planning process. However, self-evaluations differed for the two MSPs. Fewer members of the first MSP agreed because of their limited involvement as a result of their relative lack of knowledge and early stage in the learning process. Because the first MSP felt that it had little control over the process, it was likely ineffective at influencing forest management decision-making. Trust in the complex forest management planning process was, therefore, a greater issue for the first MSP. However, while findings suggest that the second MSP had a greater sense of control and influence over the process, its influence was also limited as a result of the complexity of forest management planning.

For both MSPs, most interviewees agreed that their participation resulted in an increased understanding of stakeholder and agency issues, increased cooperation between agency and stakeholders, and increased cooperation among stakeholders. These results suggest that LCCs act as a vehicle to develop social and human capital. Given the permanent nature of LCCs, the result also suggests that LCCs benefit from their long-standing work with the same members and same issues.

Evidence from the Independent Forest Audits indicated that many MSPs are dissatisfied with their level of influence. This different finding from the survey data may have arisen because only a sample of MSP members responded to the social survey. Likewise, the result may have arisen because only one-quarter of IFAs commented about satisfaction.

\section{Conclusion}

This study addressed questions about representation and success of Ontario's LCCs. We explored the multi-dimensional nature of both representation and success and concluded that representation is an issue and that LCCs have a mixed level of success.

MSP members were found to be narrowly representative of northern and southern Ontarians and tended to lack formal representation from aboriginal people and environmental and resource-based tourism stakeholders. While members tended to represent broader interests beyond those they were selected to represent, internal and external exclusion may be preventing some groups from meaningful engagement. Socialization over time may also be causing existing MSP members to become more homogeneous in terms of environmental values and attitudes towards forests and forest management. The two interviewed MSPs appear to function well, which would provide a safe environment for stakeholder representatives to freely represent their views. However, communication between MSPs and represented groups and the general public was generally one-way instead of two-way. If typical, this could become a major concern for stakeholder group representation and could undermine a key reason for the emergence of MSPs. This potential result, combined with the homogenization identified earlier, suggests that LCCs may be becoming less rather than more representative of relevant stakeholders. The potential of MSPs being captured by agency partners such as OMNR is a well-known threat to their independence (Singleton 2000).

Results were mixed regarding the success of MSPs; the social survey indicated that most LCCs were effective on the process criterion of influencing decisions but Independent Forest Audits and LCC interviews indicated that many LCCs were not effective. The determinants of effectiveness were consistent across these studies. Effectiveness was partially determined by sense of control (i.e., those who felt a sense of control felt they had influence while those that did not, did not feel they had influence). While the case studies revealed that MSPs were generally successful on short-term outcomes, such as meeting expectations and developing increased confidence in the planning process, the results varied for the two interviewed LCCs. The newer LCC had less knowledge, was more overwhelmed, and thus, had a lower sense of control versus its comparator. MSPs were also successful with respect to long-term outcomes such as increased understanding of stakeholder and agency issues and increased cooperation amongst stakeholders and agency support staff. If representative, this bodes well for the long-term future of LCCs. However, cooperation may erode if LCCs are not effective at influencing forest management decision-making.

\section{Acknowledgements}

We thank the Living Legacy Forest Research Program LL-RP09 for financial support and the Ontario Ministry of Natural Resources for financial and in-kind support for conducting the research reported on here. We also thank John Parkins for comments on an earlier manuscript.

\section{References}

Berkes, F., D. Feeny, B.J. McCay and J.M. Acheson. 1989. The benefits of the commons.

Nature 340: 91-93.

Canadian Standards Association. 2002. Standard CAN/SCAZ809-02. Sustainable forest

management: requirements and guidance. Available at http://www. csainternational.org/product_areas/forest_products_marking/ program_documents/CAN_CSA_Z809-02O_English.pdf.

Charnley, S. and B. Engelbert. 2005. Evaluating public participation in environmental decision

-making: EPA's superfund community involvement program. J. Env. Manag. 77: 165-182.

Crown Forest Sustainability Act. 1994. Statutes of Ontario. 1994, Chapter 25, as amended. Available at http://www.e-laws.gov.on.ca/ html/statutes/english/elaws_statutes_94c25_e.htm\#BK3. 
Dennis, S. 1988. Incorporating public opinion surveys in national forest land and resource planning. Society \& Natural Resources 1: 309-316.

[EAB] Environmental Assessment Board. 1994. Reasons For Decision And Decision - Class Environmental Assessment by the Ministry of Natural Resources for Timber Management on Crown Lands in Ontario. EA-87-02. Toronto, ON. 561 p.

Estes, C. 1984. Consensus. In Context 3: 19-22.

Faysse, N. 2006. Troubles on the way: An analysis of the challenges faced by multi-stakeholder platforms. Natural Resour. Forum 30: 219-229.

Fisher, R. and W. Ury. 1981. Getting to yes: negotiating agreement without giving in. Penguin, New York. 236 p.

Folger, R., D. Rosenfield, J.Grove and L. Corkan. 1979. Effects of "voice" and peer opinions on response to inequity. J. Person. Soc. Psych. 37: 2253-2261.

Forest Stewardship Council. 2004. National boreal standard. Available at http://www.fsccanada.org/SiteCM/U/D/39146450F65AB88C .pdf [Accessed November 15, 2007].

Hemmati, M. 2002. Multi-Stakeholder Processes for Governance and Sustainability: Beyond Deadlock and Conflict. Earthscan Publications Ltd., London.

Hunt, L.M., R.H. Lemelin and K.C. Saunders. 2009. Managing Forest Road Access on Public Lands: A Conceptual Model of Conflict. Society \& Natural Resources 22: 128-142.

Hunt, L.M. and B.L. McFarlane. 2002. Views about forest management in Ontario: Highlights from surveys with the Ontario public. Ont. Min. Natur. Resour, Thunder Bay CNFER TR-010. 26 p.

Hunt, L.M. and B.L. McFarlane. 2007. Understanding self-evaluations of effectiveness by forestry advisory committee members: A case of Ontario's Local Citizens Committee members. J. Env. Manag. 83: $105-114$.

Innes, J.E. 1999. Evaluating consensus building. In L. Susskind, S. McKearnan and J. Thomas-Larmer (eds.). The consensus building handbook a comprehensive guide for reaching agreement. pp. 631-675. Sage Publications, London.

Innes, J.E. and D.E. Booher. 1999. Consensus building and complex adaptive systems a framework for evaluating collaborative planning. Journal of the American Planning Association 65(4): 412-423. Jabbour, J.R. and D. Balsillie. 2003. The effectiveness of public participation in forest management: A case study analysis of the Morice Innovative Forest Practices Agreement. For. Chron. 79: 329-341.

Jackson, L.S. 2001. Contemporary public involvement: Toward a strategic approach. Local Environment 6(2): 135-147.

Lauber, T.B. and B.A. Knuth. 1999. Measuring fairness in citizen participation: A case study of moose management. Society \& Natural Resources 12: 19-37.

Lind, E.A. and E.R. Tyler. 1988. The social psychology of procedural justice. Plenum Press, New York. 284 p.

Mascarenhas, M. and R. Scarce. 2004. "The intention was good": Legitimacy, consensus-based decision making, and the case of forest planning in British Columbia, Canada. Society \& Natural Resources 17(1): 17-38.

McFarlane, B.L. and P.C. Boxall. 2000. Factors influencing forest values and attitudes of two stakeholder groups: The case of the Foothills Model Forest, Alberta, Canada. Society \& Natural Resources 13: 649-661.

McFarlane, B.L. and P.C. Boxall. 2003. The role of social psychological and social structural variables in environmental activism: an example of the forest sector. J. Env. Psych. 23: 79-87.

McFarlane, B.L. and L.M. Hunt. 2006. Environmental activism in the forest sector - Social psychological, social-cultural, and contextual effects. Env. Behav. 38: 266-285.
OFAH and NOTOA. 1991. Written direct evidence of the Ontario Federation of Anglers and Hunters (OFAH) and Northern Ontario Tourist Outfitters Association (NOTOA) coalition. Panel 2, essential requirements of public consultation. p. 44. Toronto, $\mathrm{ON}$.

[OMNR] Ontario Ministry of Natural Resources. 2002. State of the forest report, 2001. Available at http://www.web2.mnr.gov.on.ca/ $\mathrm{mnr} /$ forests/forestdoc/sofr/pdf/toc.pdf.

2007. Independent forest audit process and protocol. Queens Printer of Ontario, Toronto, ON. 190 p.

Parkins, J.R. 2002. Forest management and advisory groups in Alberta: An empirical critique of an emergent public sphere. Can. J. Sociol. / Cahiers Canadiens De Sociologie 27: 163-184.

Parkins, J.R. and R.E. Mitchell. 2005. Public participation as public debate: A deliberative turn in natural resource management. Society \& Natural Resources 18: 529-540.

Parkins, J.R., S. Nadeau, L.M. Hunt, J. Sinclair, M.G. Reed and S. Wallace. 2006. Public participation in forest management: Results from a national survey of advisory committees. Canadian Forest Service, Northern Forestry Centre, Edmonton, AB. 64 p.

Reed, M.G. and J. Varghese. 2007. Gender representation on Canadian forest sector advisory committees. For. Chron. 83: 515-525.

Robson, M. and S. Kant. 2007a. The development of government agency and stakeholder cooperation: A comparative study of two Local Citizens Committees' (LCCs) participation in forest management in Ontario, Canada. For. Pol. Econ. 9: 1113-1133.

Robson, M. and S. Kant. 2007b. Structure of causation and its influence on cooperation: A comparative study of forest management in Ontario, Canada. For. Pol. Econ. 10: 70-81.

Robson, M., J. Rosenthal, R.H. Lemelin, L.M. Hunt and N. McIntyre. (In press). Information complexity as a constraint to public involvement in sustainable forest management. Society \& Natural Resources.

Rowe, G., and L.J. Frewer. 2000. Public participation methods: A framework for evaluation. Science Tech. Hum. Val. 25: 3-29.

Shindler, B., P. List and B. Steel. 1993. Managing federal forests: Public attitudes in Oregon and nationwide. J. For. 91: 36-42.

Sheppard, S.R.J. and M. Meitner. 2005. Using multi-criteria analysis and visualisation for sustainable forest management planning with stakeholder groups. For. Ecol. Man. 207: 171-187.

Singleton, S. 2000. Co-operation or capture? the paradox of comanagement and community participation in natural resource management and environmental policymaking. Environmental Politics 9(2): 1-21.

Steins, N.A. and V.M. Edwards. 1999. Collective action in common pool resource management: the contribution of a social constructivist perspective to existing theory. Society \& Natural Resources 12: 539-557.

Tuler, S. and T. Webler. 1999. Voices from the forest: What participants expect of a public participation process. Society \& Natural Resources 12(5): 437-453.

Wellstead, A.M., R.C. Stedman and J.R. Parkins. 2003. Understanding the concept of representation within the context of local forest management decision making. For. Policy Econ. 5: 1-11.

Wollenberg, E., A. Uluk, R. Iwan, G. Limberg, M. Moeliono and M. Sudana. 2004. Representation: Who speaks for whom in citizendriven research? Paper presented at the Xth Meeting of the International Association for the Study of Common Property, 9-13 August 2004, Oaxaca, Mexico. CIFOR, Bogor, Indonesia. 21 p. 